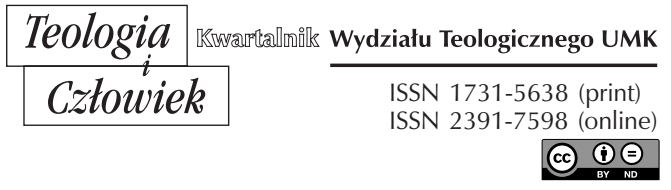

43(2018)3, ss. 99-122

KS. MAREK FILIPCZUK WYDZIAŁ TEOLOGICZNY UNIWERSYTETU KARDYNAŁA STEFANA WYSZYŃSKIEGO W WARSZAWIE

\title{
BUDOWANIE DOMU NA SKALE - O CHRZEŚCIJAŃSKIEJ WIZJI PROCESU WYCHOWANIA
}

DOI: http://dx.doi.org/10.12775/TiCz.2018.029

Streszczenie. Personalizm chrześcijański, w którym przyjmuje się podstawową rzeczywistość Boga osobowego i człowieka jako osoby, jest na właściwej drodze do zrozumienia w pełni pojęcia osobowości, łączącego w sobie zarazem duchowość, indywidualne piętno oraz uspołecznienie jako nierozłączne rysy istoty człowieka. W pedagogice w pierwszej kolejności chodzi o odpowiedź na fundamentalne dla teorii wychowania pytania, które brzmią: kim jest człowiek i jaka jest jego natura? Na tym opiera się określenie celu wychowania, odniesienie do odpowiedniego systemu wartości, czyli związku etyki i wychowania, a także określenie elementów konstytuujących harmonijny i integralny rozwój osobowości jako normy personalistycznej.

Pedagogika personalistyczna kładzie nacisk na afirmację osoby, wychowuje w postawie chronienia relacji z innymi osobami i całym otoczeniem człowieka. $\mathrm{Z}$ pomocą przychodzi kształcenie i wychowanie rozumności człowieka i jego wolności; kształcenie wyobrażeń i wychowanie uczuć. Jest tu zarówno miejsce na chronienie powiązań przez przyjaźń i miłość z innymi ludźmi, jak i na budowanie właściwej relacji z Bogiem w religii. Wychowanie polega na nawiązaniu relacji z tym, co prawdziwe i dobre, słuszne i właściwe; ma zaowocować zharmonizowaniem całej osobowości człowieka.

Słowa kluczowe: antropologia chrześcijańska; Jezus Chrystus; moralność; pedagogika personalistyczna; wychowanie. 


\section{Abstract. Building a House on the Rock - On Christian Vision of the Process} of Upbringing. Christian personalism which accepts the fundamental reality of God-the Father and man-a person is the right path leading to full understanding of the concept of personality as a combination of spirituality, individual traits and socialization which are inseparable features of human person. Pedagogy gives priority to problems essential for the theory of education, namely 'Who is a man' and 'What is his nature. The reply to these questions determines the goal of upbringing, the reference to the appropriate system of values, that is the connection of ethics and education, as well as defines the components which are responsible for a harmonious and integral development of personality according to the personalistic norm.

Personalistic pedagogy places emphasis on the affirmation of a person and on such upbringing which protects relationships with other people and man's whole environment. The immanent elements of this way of upbringing are the formation of man's rationality and his freedom, as well as that of his world outlook and emotions. It allows space for the protection of relationships with - through friendship with and love for - other people, and creating relations with God through religious education. Such upbringing consists in building relations with everything that is genuine and kind, upright and honest- thus being aimed at the harmonious growth of man's entire personality.

Key words: Christian anthropology; Jesus Christ; morality; personalistic pedagogy; upbringing.

Niezwykle ważnym etapem w rozwoju myśli pedagogicznej było przyjście Jezusa Chrystusa oraz powstanie chrześcijańskiej koncepcji świata, człowieka, życia, wychowania. Podstawowymi zdobyczami, ważnymi w dziedzinie pedagogiki okazały się: wprowadzenie zasady równości wszystkich ludzi i nowego systemu wartości, wyprowadzenie zasad odnoszących się do wychowania z pozycji wiary religijnej (cnoty kardynalne i teologalne, przykazanie miłości bliźniego), zaakcentowanie podmiotowości i odpowiedzialności człowieka za wszelkie czyny podejmowane w sposób świadomy, podkreślenie szczególnej wartości dzieciństwa ${ }^{1}$. Na przestrzeni wieków wymienione założenia wychowawcze stały się dziedzictwem pokoleń i znalazły swoją praktyczną realizację w licznych inicjatywach oświatowo-wychowawczych prowadzonych przez Kościół².

1 Por. M. Nowak, Podstawy pedagogiki otwartej, Lublin 1999, s. 82-83.

2 Szerzej na ten temat zob. R. Murawski, Rys historyczny lekcji religii katolickiej w Europie, w: Nauczanie religii katolickiej w szkole, „Studia Katechetyczne” 7 (2010), s. $25-46$. 


\section{ROZWÓJ MYŚLI FILOZOFICZNEJ PERSONALIZMU}

Chrześcijaństwo ze swoim dorobkiem wprowadza do świata kultury i praktyki wychowawczej zdecydowanie nowy model wychowania, który przez kolejne stulecia będzie kształtował pedagogię, instytucje i ośrodki wychowawcze, szkolne i pozaszkolne na całym świecie. Model ten stawia w centrum osobę Jezusa Chrystusa, Boga-Człowieka i Zbawiciela. Jego podstawę doktrynalną stanowią pisma Nowego Testamentu, które z czasem zostają ubogacone pismami Ojców Kościoła, apologetów chrześcijaństwa, filozofią i teologią scholastyczną Średniowiecza, dokumentami soborów, papieży, zakonów, doświadczeniem religijnym wierzących ${ }^{3}$.

Historycznie rzecz biorąc, chrześcijańska wizja życia wytrzymała próbę czasu przede wszystkim w świecie zachodnim. Świadczy o tym refleksja pedagogiczna i praktyka edukacyjna licznych szeregów wychowawców, którzy czerpali z Ewangelii inspiracje i motywy swojego działania. Zasady ewangeliczne przenikały działanie osób i instytucji, które poświęciły się nauczaniu i wychowaniu, przyjmując jako podstawę i horyzont sensu swej działalności nauczanie Jezusa Chrystusa i teologiczno-egzystencjalne przesłanie chrześcijaństwa: nowe spojrzenie na człowieka w perspektywie wiary, modlitwa, życie liturgiczne, praktyka sakramentalna, służba braciom ${ }^{4}$.

Trzeba jednak stwierdzić, że chrześcijaństwo pierwszych wieków, zachowując pewną linię ciągłości z dziedzictwem żydowskim, nie wypracowało własnej pedagogiki ani dydaktyki w sensie ścisłym. Pisma Nowego Testamentu nie zawierają bowiem organicznej i systematycznej doktryny na temat rzeczywistości wychowawczej. Tym niemniej, w Ewangeliach i Listach św. Pawła można znaleźć cenne wskazówki, bezpośrednie lub pośrednie, odnoszące się do tego wymiaru ludzkiego życia. Najważniejszymi ideami wychowawczymi są: zwrócenie uwagi na osobę dziecka, postrzeganie życia jako ciągłego wzrastania ku dojrzałości ludzkiej i chrześcijańskiej, mocne zaakcentowanie odpowiedzialno-

${ }^{3} \mathrm{Na}$ temat fundamentów chrześcijańskiego modelu wychowania zob. Benedykt XVI, Deus caritas est. Encyklika o miłości chrześcijańskiej, Watykan 2005, nr 1, 11.

${ }^{4} \mathrm{~W}$ opracowaniu chrześcijańskiej wizji wychowania wykorzystano głównie: A. Orczyk, Założenia filozoficzne $i$ wychowawcze chrześcijańskiej pedagogiki personalistycznej, „Zeszyty Formacji Katechetów” 2 (2004), s. 39-43. 
ści wychowawczej rodziców, uwzględnianie prawdy o ostatecznym celu wychowania.

Pedagogika personalistyczna nawiązuje do personalizmu filozoficznego Jacquesa Maritaina (1882-1973) i Emmanuela Mouniera (19051950) i postuluje źródłowe (ejdetyczne) ujęcie pedagogiki, która powinna kształtować swoją tożsamość nie tyle w oparciu o przesłanki ideologiczne lub metodyczne, ale przede wszystkim wychodząc od zrozumienia bytu ludzkiego jako takiego. Podstawowym wyznacznikiem personalizmu jest twierdzenie,

że człowiek - zanim zostaną mu przypisane jakieś nazwy, cechy bądź właściwości - jest osobą; bycie osobą, stanowiące fakt pierwotny i nieredukowalny, ma charakter etyczny - do pojęcia osoby przynależą bowiem wolność, szacunek, równość, tolerancja, ale także i odpowiedzialność; wychowanie w pedagogice personalistycznej ma charakter spotkania dwóch osób, nauczyciela (mistrza) i ucznia, którym przysługuje ta sama godność etyczna; owo spotkanie dokonuje się w konkretnej rzeczywistości, stąd też zadaniem pedagogiki personalistycznej jest ujawnianie podstawowego sensu wychowania, jakim jest spotkanie osób, w jego uwarunkowaniach historycznych, społecznych, politycznych i kulturowych ${ }^{5}$.

Z punktu widzenia rozważań pedagogicznych można mówić o pewnych liniach, sposobach rozumienia pojęcia osoby w myśli filozoficznej personalizmu, co ma podstawowe znaczenie dla refleksji i praktyki pedagogiczno-wychowawczej. Osoba jest tutaj postrzegana jako istota niezależna, będąca w relacji do innych, ukierunkowana na najwyższe dobro w kategoriach etyczno-moralnych, posiadająca indywidualny charakter aktów psychicznych ${ }^{6}$.

W wychowaniu chrześcijańskim personalizm ma wymiar egzystencjalny, stąd wynika prawda, że

osoba jest podmiotem i celem wychowania i w tym sensie ma pierwszorzędny i niepowtarzalny walor wyrażający się w jej nadrzędności względem wszelkich wartości materialnych oraz struktur społecznych

${ }_{5}$ Pedagogika. Leksykon PWN, red. B. Milerski, B. Śliwerski, Warszawa 2000, s. 155.

6 Por. M. Nowak, Wychowanie w personalizmie, ChS 4 (1993), s. 60-64. 
i ekonomicznych, które winny być podporządkowane dobru osoby ludzkiej i służyć jej rozwojowi przy pełnym poszanowaniu wolności

Chrześcijański proces wychowania opiera się ponadto na idei chrystocentryzmu, z którego wynikają inne, charakterystyczne dla niego elementy, takie jak odniesienie moralne, personalizm i humanizm chrześcijański.

Personalizm zakłada postrzeganie ucznia w kategoriach jego podmiotowości, godności, wolności, konkretnych praw i obowiązków ${ }^{8}$. Koncepcja personalistyczna jest odpowiedzią na najbardziej egzystencjalne pytania tkwiące w najgłębszych pokładach bytu ludzkiego: kim jest człowiek? Jaki jest otaczający nas świat? Jaka jest rola człowieka w tym świecie, czyli jaki jest sens życia człowieka??

Prawdziwe wychowanie, zgodnie z nauczaniem soborowym zawartym w deklaracji o wychowaniu chrześcijańskim Gravissimum educationis,

zdąża do kształtowania osoby ludzkiej w kierunku jej celu ostatecznego, a równocześnie do dobra społeczności, których człowiek jest członkiem i w których obowiązkach, gdy dorośnie, będzie brał udział. ${ }^{10}$ Należy więc zgodnie z postępem nauk psychologicznych, pedagogicznych i dydaktycznych dopomagać dzieciom i młodzieży do harmonijnego rozwijania wrodzonych właściwości fizycznych, moralnych i intelektualnych, do zdobywania stopniowo coraz doskonalszego zmysłu odpowiedzialności w należytym kształtowaniu własnego życia przez nieustanny wysiłek i w osiąganiu prawdziwej wolności, po wielkodusznym i stanowczym przezwyciężeniu przeszkód ${ }^{11}$.

7 M. Cichosz, Wychowanie chrześcijańskie, w: Pedagogika ogólna. Problemy aksjologiczne, red. T. Kukołowicz, M. Nowak, Lublin 1997, s. 181.

8 Por. M. Cogiel, Wychowanie personalistyczne wobec nowego paradygmatu edukacji, AK 136 (2001) 552, s. 283.

9 Por. tamże, s. 284.

${ }^{10}$ Osoba jest podmiotem procesu rozwoju. J. Majka tak to ujmuje: „Sam rozwój, doskonalenie, kształtowanie osoby jest i musi być jej dziełem, owocem jej wysiłków. Wynika to zresztą nie tylko $\mathrm{z}$ autonomicznego charakteru osoby, z jej podstawowej ontologicznej wolności, ale także $\mathrm{z}$ analizy samego procesu przekazywania i przyswajania wartości osobowych". J. Majka, Wychowanie chrześcijańskie - wychowaniem personalistycznym, ChS 42-43 (1976), s. 5.

11 GE 1. 


\section{ZAłOŻENIA WYCHOWAWCZE CHRZEŚCIJAŃSKIEJ PEDAGOGIKI PERSONALISTYCZNEJ}

Bogata refleksja pedagogiczna na temat wychowania $\mathrm{w}$ ujęciu chrześcijańskim doczekała się licznych opracowań ${ }^{12}$. Fundamentalne założenia wychowawcze chrześcijańskiej pedagogiki personalistycznej można ująć w następujących zasadach:

- wychowanie powinno służyć promocji osoby jako jednostki i jako wspólnoty osób;

- pierwszym i podstawowym celem wychowania jest doprowadzenie wychowanka do przejęcia kierownictwa nad własnym procesem całościowego rozwoju ${ }^{13}$;

- realistyczne ujęcie relacji wychowawczej między wychowawcą a wychowankiem zakłada uznanie aktywnej roli każdej ze stron;

- wychowanie w ujęciu chrześcijańskim musi krytycznie podchodzić zarówno do redukcjonizmu naturalistycznego, jak i do indywidualistycznego optymizmu w patrzeniu na człowieka, aby uniknąć błędów kolektywizmu i indywidualizmu;

- uznanie autonomii osoby wychowanka broni go przed traktowaniem jako rzeczy i przed hegemonistycznym wpływem jakiejś instancji wychowawczej;

- przyjmuje się wzajemną zależność od siebie takich elementów, jak względny indeterminizm, wolność, tolerancja w realizacji procesu wychowawczego;

- rodzina uważana jest za podstawowe środowisko i instytucję wychowawczą, zdając sobie jednak sprawę z kryzysu, jaki ona przeżywa i z zagrożeń, jakie mogą wystąpić w wychowaniu

12 Zob. Wychowanie chrześcijańskie a kultura, red. M. Nowak, T. Ożóg, Lublin 2000; R. Rybicki, Wprowadzenie do pedagogiki chrześcijańskiej, Częstochowa 1997; J. Tarnowski, Jak wychowywać?, Warszawa 1993; Pedagogika katolicka. Zagadnienia wybrane, red. A. Rynio, Stalowa Wola 1999; S. Dziekoński, Wychowanie w nauczaniu Kościoła od XIX w. do Soboru Watykańskiego II, Warszawa 2000; Katolicka a liberalna myśl wychowawcza w Polsce w latach 1918-1939, red. E. Walewander, Lublin 2000; K. Jędrzejczak, Katolicka myśl pedagogiczna w Drugiej Rzeczypospolitej (założenia - problematyka badań - osiagnięcia), Wolsztyn 1998.

13 Por. Z. Matulka, Samowychowanie chrześcijańskie, Toruń 1995, s. 43-49. 
rodzinnym $\mathrm{w}$ postaci autorytaryzmu rodziców, przemocy, patologii. „Rodzice, ponieważ dali życie dzieciom, w najwyższym stopniu są obowiązani do wychowania potomstwa i dlatego muszą być uznani za pierwszych i głównych wychowawców. To zadanie wychowawcze jest tak wielkiej wagi, że jego ewentualny brak z trudnością dałby się zastąpić. Do rodziców bowiem należy stworzyć taką atmosferę rodzinną, przepojoną miłością i szacunkiem dla Boga i ludzi, aby sprzyjała całemu osobistemu i społecznemu wychowaniu dzieci. Dlatego rodzina jest pierwszą szkołą cnót społecznych, potrzebnych wszelkim społecznościom"14;

- instytucja szkoły jest nadal kluczową instytucją wychowawczą, która jednocześnie uznaje prawo rodziców do decydowania o procesie i kształcie wychowania swoich dzieci. „Między wszystkimi środkami wychowania szczególne znaczenie ma szkoła, która mocą swego posłannictwa kształtuje z wytrwałą troskliwością władze umysłowe, rozwija zdolność wydawania prawidłowych sądów, wprowadza w dziedzictwo kultury wytworzone przez przeszłe pokolenia, kształci zmysł wartości, przygotowuje do życia zawodowego, sprzyja dyspozycjom do wzajemnego zrozumienia się, stwarzając przyjazne współżycie wśród wychowanków różniących się charakterem i pochodzeniem; ponadto stanowi jakby pewne centrum, w którego wysiłkach i osiągnięciach powinny uczestniczyć równocześnie rodziny, nauczyciele, różnego rodzaju organizacje rozwijające życie kulturalne, obywatelskie, religijne, państwowe i cała społeczność ludzka"15;

- niekwestionowane prawo wypełniania obowiązku wychowawczego zachował Kościół, który realizuje je przede wszystkim poprzez prowadzenie katechizacji i zakładanie szkół katolickich ${ }^{16}$. Kościół stoi na stanowisku, że władze państwowe, uwzględniając

${ }^{14}$ GE 3.

15 GE 5.

${ }^{16}$ Por. T. Kadziński, Powinność wychowawcza Kościoła - szkoła katolicka, w: „Paedagogia Christiana” 4 (1999), s. 104-112. 
pluralizm dzisiejszego społeczeństwa i szanując wolność religijną, powinny pomagać rodzinom, aby „wychowanie dzieci we wszystkich szkołach mogło się odbywać zgodnie z własnymi zasadami moralnymi i religijnymi tych rodzin" ${ }^{17}$;

- władza państwowa ma do spełnienia kluczowe zadania w zakresie tworzenia systemu edukacyjnego i organizacji szkolnictwa. Administracja państwowa powinna „zabezpieczyć prawo młodzieży do odpowiedniego wychowania szkolnego, czuwać nad zdatnością nauczycieli i wysokim poziomem nauki, troszczyć się o zdrowie wychowanków i w ogóle doskonalić całą organizację szkolnictwa, pamiętając o zasadzie pomocniczości i dlatego wykluczając wszelki monopol szkolny, który sprzeciwia się wrodzonym prawom osoby ludzkiej, a także postępowi i upowszechnianiu samej kultury, pokojowemu współżyciu obywateli i pluralizmowi istniejącemu dziś w bardzo licznych społeczeństwach"18;

- docenia się rolę środków nadprzyrodzonych w procesie wychowania: cnót wiary, nadziei i miłości, życia w łasce uświęcającej, życia sakramentalnego, modlitwy ${ }^{19}$.

Ta ostatnia zasada sugeruje konieczność odniesienia się do wychowania religijnego, które odwołuje się do faktu, że człowiek jest obrazem Boga. Ma tu swoje źródło podstawowa dla wychowania prawda o celowości życia ludzkiego. Wyraża ją Katechizm Kościoła Katolickiego:

Bóg nieskończenie doskonały i szczęśliwy zamysłem czystej dobroci, w sposób całkowicie wolny stworzył człowieka, by uczynić go uczestnikiem swego szczęśliwego życia. Dlatego w każdym czasie i w każdym miejscu jest On bliski człowiekowi. Powołuje go i pomaga mu szukać, poznawać i miłować siebie ze wszystkich sił. Wszystkich ludzi rozproszonych przez grzech zwołuje, by zjednoczyć ich w swojej rodzinie Kościele. Czyni to przez swego Syna, którego posłał jako Odkupiciela i Zbawiciela, gdy nadeszła pełnia czasów. W Nim i przez Niego Bóg

17 GE 7.

18 GE 6.

19 Por. M. Nowak, Wychowanie w personalizmie, s. 64-65; zob. M. Cogiel, Kontrowersje wokót wychowania. Dylematy teorii i praktyki edukacyjnej, „Śląskie Studia Historyczno-Teologiczne" 27-28 (1995), s. 60-63. 
powołuje ludzi, by w Duchu Świętym stali się Jego przybranymi dziećmi, a przez to dziedzicami Jego szczęśliwego życia ${ }^{20}$.

\section{DYCHOTOMICZNOŚĆ NATURY LUDZKIEJ}

Podstawowym zadaniem wychowania religijnego jest także pomoc w osiągnięciu pełni człowieczeństwa. Człowiek może ją osiągnąć, jeżeli w wychowaniu znajdzie potwierdzenie własnej tożsamości, mając jasny i trwały obraz samego siebie ${ }^{21}$. Poznanie tego obrazu jest $z$ kolei uzależnione od właściwego rozumienia natury człowieka, która jest zarazem zdolna do dobra i zła. Problematykę tę charakteryzuje dosyć dobrze Marceli Cogiel, stwierdzając:

Człowiek ze swej natury jest zdolny do dobra. Skoro jednak jego natura została skażona grzechem, człowiek jest również zdolny do zła. Chrześcijańskie spojrzenie na kondycję moralną człowieka jest w pełni realistyczne: jest on istotą ambiwalentną. Pedagogia chrześcijańska uwzględnia właśnie tę dwuznaczność. Wie, że zło może nami owładnąć i że ma wielką siłę przyciągania. [...] Wychowanie religijne jest procesem stale podejmowanych działań, które mają na celu utrwalenie i pogłębienie więzi łączących człowieka $\mathrm{z}$ Bogiem i Boga $\mathrm{z}$ człowiekiem, sprawianą $\mathrm{w}$ nas przez Chrystusa. Wychowanie to charakteryzuje się tym, że jest zespołem czynności niedokonanych. W teologii ascetycznej nazywa się ten stan nieustannym nawracaniem. [...] Celem wychowania chrześcijańskiego tylko wtórnie jest kształtowanie poglądów w duchu nauki Bożej, celem nadrzędnym jest bowiem skłanianie siebie i bliźnich do otwierania się na zbawczą moc Bożą (por. 1 Kor 2,4n.) 22 .

\section{${ }^{20}$ KKK 1.}

${ }^{21}$ Dążenie do doskonałości, pokonanie rozpiętości między człowiekiem, którym chcę być, a człowiekiem realnym, może dokonywać się za sprawą działania - bycia w prawdzie, dobru i pięknie wobec innych ludzi i świata. Prawda, dobro i piękno uważane są za wartości uniwersalne. Por. T. Kukołowicz, Wychowanie - arcyludzki problem, w: Wychowawca na czas próby. Jakiego człowieka chcemy wychować?, Marki-Struga 1997, s. $11-12$.

${ }^{22}$ M. Cogiel, Kontrowersje wokół wychowania, s. 62; por. M. Nowak, Wychowanie religijne w pedagogice katolickiej XX wieku, „Paedagogia Christiana” 1 (2001), s. 43-69; R. Niparko, Wychowanie religijne jako wychowanie humanistyczne - perspektywa personalistyczna, „Paedagogia Christiana” 2 (2003), s. 9-22. 
Pierwszym zadaniem wychowania religijnego jest pomoc udzielana człowiekowi, aby ten stał się nim rzeczywiście, w pełnym wymiarze ${ }^{23}$. Dla wychowania religijnego, które zmierza do tego, aby został udoskonalony typ relacji człowieka z Bogiem i Boga z człowiekiem, a przez to także relacji międzyludzkich, prawda o człowieku jako obrazie Boga posiada znaczenie zasadnicze ${ }^{24}$.

Wychowanie religijne jest powołane do stawania się adwokatem zagrożonego człowieka, nie tylko umieszczając pochopnie chrześcijańskie etykiety na doświadczeniu ludzkim, czy organizując to życie w jakiś system, ale wzmacniając człowieka, aby pozostał on otwarty na sens. Jest jego podstawową funkcją, aby służyło człowiekowi, który dzisiaj zanurzony jest w ryzyko niemożności znalezienia sensu, poprzez przytłoczenie niezliczonymi racjonalnymi wyjaśnieniami ${ }^{25}$. Tymczasem życie ludzkie realizuje się nie tylko w obszarze racjonalnych dociekań, czy w sferze egzystencjalnej pragmatyki (troska o dobra materialne), ale także przede wszystkim w obszarze tajemnicy wynikającej z faktu stworzenia i Wcielenia ${ }^{26}$.

Nie może istnieć społeczeństwo godne człowieka bez szacunku dla wartości transcendentnych i trwałych. Kiedy człowiek czyni siebie miarą wszystkiego, bez odniesienia do Tego, od którego wszystko pochodzi i do którego świat ten powróci, ów człowiek bardzo szybko staje się niewolnikiem własnej skończoności ${ }^{27}$.

Nawet ci, którzy głośno reklamują swą autonomię i radosną wolność, przyciśnięci do muru, przyznają się do bezradności i zagubienia, a co najważniejsze do niemożności sensu życia i... sensu śmierci. Pustkę próbują pokrywać cynizmem. Są żywymi świadkami prawdy, że tylko

${ }^{23}$ Por. K. Misiaszek, Wychowanie chrześcijańskie w świetle Katechizmu Kościoła Katolickiego, s. 90.

${ }^{24}$ Por. tamże, s. 20.

25 Zob. A. Exeler, Leducatione religiosa. Unitinerario alla maturazione dell'uomo, Torino 1990, s. 30-31.

${ }^{26}$ Por. K. Misiaszek, Wychowanie chrześcijańskie w świetle Katechizmu Kościoła Katolickiego, s. 96.

${ }^{27}$ Jan Paweł II, Przemówienie noworoczne do dyplomatów na początku roku 1990. 
Bóg daje poczucie sensu wszystkiego ${ }^{28}$. Jak czytamy w instrukcji Libertatis nuntius:

W odniesieniu do nowożytnego ruchu wewnętrznego wyzwolenia człowieka trzeba stwierdzić, że wysiłek mający na względzie wyzwolenie myśli i woli z ich ograniczeń, doprowadził niektórych do przekonania, że moralność jako taka stanowi irracjonalną przeszkodę, którą człowiek zdecydowany, by stać się panem samego siebie, ma prawo przezwyciężyćc ${ }^{29}$.

\section{ANTROPOLOGICZNY FUNDAMENT PEDAGOGIKI PERSONALISTYCZNEJ}

U podstaw każdej teorii wychowania i każdej praktyki wychowawczej stoi jakaś koncepcja człowieka, z natury rzeczy u podstaw chrześcijańskiej teorii wychowania i chrześcijańskiej praktyki stoi chrześcijańska koncepcja człowieka. Stwierdza ona przede wszystkim, jaki człowiek jest oraz jaki powinien być, a zatem określa rzeczywistość stanowiącą przedmiot zabiegów wychowawczych oraz szkicuje ideał stanowiący ich ukoronowanie ${ }^{30}$.

Podstawą tych wypaczeń, jak zauważył Jan Paweł II, jest błąd antropologiczny, czyli błędne rozumienie człowieka. To błędne rozumienie człowieka jest w kulturze jakoś faworyzowane; kolejne wielkie epoki jakoś specjalizują się, by opracować i przedstawić koncepcję człowieka ${ }^{31}$. Współcześnie żyjemy w kulturze opartej na bardzo zdeformowanej koncepcji człowieka. Człowiek jest rozumiany jako zwierzę, albo jako bóg-absolut, który od wszystkiego jest uwolniony. Jesteśmy współcześnie dziedzicami pewnych wizji człowieka powstałych w kulturze europejskiej w ciągu dwóch tysięcy lat. Są to trzy wielkie koncepcje człowieka: platońska, ary-

${ }^{28}$ Por. L. Knabit, Ojcostwo rodem z Ducha Świętego, „Pastores” 2 (1999) 1, s. $45-46$.

29 Kongregacja Nauki Wiary, Libertatis nuntius. Instrukcja, w: Dokumenty Kongregacji Nauki Wiary 1966-1994, opr. Z. Zimowski, J. Królikowski, Tarnów 1995, p. 18, s. 249.

30 Por. P. Góralczyk, Trudny proces wychowania, s. 155.

31 Por. M.A. Krąpiec, Człowiek podmiotem wychowania, „Zeszyty Formacji Katechetów" 4 (2004) 2, s. 25. 
stotelesowska i chrześcijańska (w dużej mierze syntetyzująca poprzednie w koncepcji człowieka jako bytu osobowego, osoby) ${ }^{32}$.

Widać z tego wyraźnie, jak istotne jest właściwe odczytanie pełnej prawdy o człowieku, a więc integralna koncepcja życia ludzkiego. Jeśli bowiem zostanie zafałszowana prawda o człowieku, zostaje tym samym zniekształcona hierarchia wartości ${ }^{33}$. Warto w tym miejscu odwołać się do słów Jana Pawła II, który podczas trzeciej pielgrzymki do Polski, w przemówieniu do przedstawicieli nauki mówił w auli KUL-u:

Właśnie poprzez refleksje nad własnym poznaniem, człowiek objawia się samemu sobie jako jedyne jestestwo pośród świata, które widzi się «od wewnątrz» związane z poznaną prawdą - związane, a wiec także «zobowiązane» do jej uznania, w razie potrzeby także aktami wolnego wyboru, aktami świadectwa na rzecz prawdy. Jest to uzdolnienie do przekraczania siebie w prawdzie [...]. Człowiek zauważa po prostu, że jest osobowym podmiotem, osobą. Staje oko w oko wobec swojej godności! ${ }^{34}$

Papież wskazał jednocześnie, że to uznanie prawdy o człowieku nie jest sprawą prostą. Stąd:

Człowiek też musi w imię prawdy o samym sobie przeciwstawić się dwojakiej pokusie; pokusie uczynienia prawdy o sobie poddaną swej wolności oraz pokusie uczynienia siebie poddanym światu rzeczy, musi się oprzeć zarówno pokusie samoubóstwienia, jak i pokusie samourzeczowienia [...]. Człowiek już «od początku» nęcony jest pokusą poddania prawdy o sobie władzy swej woli i umieszczenia się przez to „poza dobrem i złem”. Kuszony jest iluzją, że prawdę o dobru i złu pozna dopiero wtedy, gdy sam będzie o niej decydowat ${ }^{35}$.

Teoria oraz praktyka wychowania są często uzależnione od przyjętej wizji człowieka i jego przeznaczenia. Pedagodzy uznają, że opis celu wychowania - czyli osoby dojrzałej - wychowanej, nie zależy od peda-

32 Por. tamże, s. 25.

33 Por. J. Nagórny, Chrześcijańskie wychowanie do wartości moralnych, s. 79.

34 Jan Paweł II, Przemówienie do przedstawicieli świata nauki (Lublin, 9 VI 1987), w: Jan Paweł II, Pielgrzymki do Ojczyzny, red. J. Poniewierski, Kraków 1997, s. 398.

35 Tamże. Koncepcja człowieka stanowi punkt wyjścia dla rozważań dotyczących problematyki wychowania, w szczególności zaś wychowania moralnego. 
gogiki, lecz do filozofii człowieka i etyki ${ }^{36}$. Zgadza się z tym poglądem Jan Paweł II, mówiąc: „Tylko wtedy, gdy dobrze się zrozumiało, kim jest człowiek sam w sobie i co jest ostatecznym celem ludzkiego życia, poprawnie i logicznie wyłania się problem, jak prowadzić człowieka do osiągnięcia przezeń osobistego celu" ${ }^{37}$.

Spośród wielu ujęć wychowania proponowanych przez różnego typu nurty współczesnej pedagogiki czy psychologii szczególnie ważna staje się analiza przyjętej koncepcji człowieka i świata w ogóle, na podstawie której tworzona jest dana wizja wychowania. Każda próba zgłębienia procesu wychowania prowadzi do stawiania sobie pytania o to, kim jest ta osoba, którą pragniemy wychować, jakie są uwarunkowania rozwoju młodego człowieka, jaki powinien być sens i rodzaj podejmowanych działań, jakie zakładane cele i jakie wartości, w świetle których proces wychowania nabierałby najgłębszego znaczenia ${ }^{38}$.

Powszechnie wiadomo, że brak prawidłowego fundamentu antropologicznego w ustaleniach prawnych lub w praktyce społecznej prowadzi do wynaturzeń, zaś podejmowane wysiłki i działania społeczne kończą się niepowodzeniem ${ }^{39}$. Nie da się w pełny sposób zinterpretować życia ludzkiego, jeśli nie ukaże się najpierw pełnej prawdy o tym, że człowiek czy byt jest częścią historii zbawienia, której twórcą jest Bóg ${ }^{40}$.

Nie bez znaczenia pozostaje także fakt, jaką koncepcję człowieka przyjmiemy w wychowaniu ${ }^{41}$, albowiem odpowiedź na pytanie: kim naprawdę jest człowiek?, ma kardynalne znaczenie dla współczesnej cywilizacji $^{42}$. Jest tak dlatego, ponieważ pytania o człowieka nie można odrywać

${ }^{36}$ Por. S. Gałkowski, Celowość a wychowanie, w: Wybrane zagadnienia z psychologii wychowawczej, red. A. Gała, Wrocław 1994, s. 10.

${ }^{37}$ Jan Paweł II, Przemówienie na uniwersytecie w Padwie (12.09.1982), w: Jan Paweł II, Wiara i kultura, Rzym-Lublin 1998, s. 163-163.

${ }^{38}$ Według papieża Franciszka wychowanie to nie tylko ciężka praca, ale też powołanie, radość i pasja. Zob. Jorge Mario Bergoglio, papież Franciszek, Wymagania i pasja. O wychowaniu chrześcijańskim, Kraków 2013.

39 Por. M. Cogiel, Wychowanie personalistyczne wobec nowego paradygmatu edukacji, s. 283.

40 Por. tamże, s. 284.

${ }^{41}$ Por. J. Bagrowicz, Katecheza jako wychowanie, „Horyzonty Wiary” 7 (1996), s. 45 .

${ }^{42}$ Por. S. Wielgus, Kościół katolicki dziś, „Nasz Dziennik”, 16-17 XI 2002, s. 13. 
od pytania o Boga. Więcej, nie sposób mówić poprawnie o człowieku, jeśli nic nie mówi się jednocześnie o Bogu ${ }^{43}$.

Odpowiedź na to pytanie wymaga wyboru i pewnej koncepcji poznawczej ${ }^{44}$. Przyjęty system wartości stanowi zaś podstawę wyboru określonego postępowania oraz celu i sensu życia ${ }^{45}$. Nie istnieje bowiem teoria, która uważałaby za możliwe wychowanie z pominięciem celów do zrealizowania i osiągnięcia ${ }^{46}$. Nie jest oczywiście obojętne z moralnego punktu widzenia, jaka jest to działalność i jaki jest cel, ku któremu zmierza, oraz jakie są motywy działającego podmiotu. ${ }^{47}$ Jeśli więc chcemy, by wychowanie człowieka miało solidne i pełne podstawy, powinno opierać się ono na chrześcijańskiej koncepcji człowieka, nie dlatego tylko, że cała nasza cywilizacja jest faktycznie nią przeniknięta, lecz dlatego, że jest to najprawdziwsza koncepcja człowieka ${ }^{48}$. Jej fundamentalna teza brzmi następująco: człowiek jest stworzony na obraz Boży i na Boże podobieństwo $^{49}$. Wszystko to, co mówi się następnie o zasadach postępowania człowieka, wynika $\mathrm{z}$ takiej wizji rozumienia człowieka ${ }^{50}$.

\section{CEL WYCHOWANIA - INTEGRALNA WIZJA CZŁOWIEKA}

Janusz Tarnowski w wywiadzie przeprowadzonym przez miesięcznik „Więź” przyznaje, że rzeczywiście zbyt mało mówi się dzisiaj o antropologicznych podstawach chrześcijańskiej koncepcji wychowania ${ }^{51}$.

${ }^{43}$ Por. M. Graczyk, Moralna część Katechizmu Kościoła Katolickiego. Jak odczytywać treści tej części Katechizmu?, „Studia Podlaskie” 1 (1994), s. 97.

${ }^{44}$ Por. W. Pasternak Dydaktyka wartości, w: Człowiek - wychowanie - kultura, red F. Adamski, Kraków 1993, s. 149.

${ }^{45}$ Por. J. Szpet, Ewangelizacyjny wymiar szkolnych lekcji religii, w: Katecheza ewangelizacyjna w rodzinie, parafii, szkole, red. S. Dziekoński, Warszawa 2002, s. 200.

${ }^{46}$ Por. G.F. D’Arcais, Propozycja personalistyczna, w: Człowiek - wychowanie kultura, s. 88.

47 Por. W. Cichoń, Aksjologiczne ujęcie procesu wychowania, w: Człowiek - wartości - wychowanie, red. F. Adamski, Kraków 1993, s. 127.

48 Por. J. Maritain, Od filozofii człowieka do filozofii wychowania, s. 64.

49 Por. KKK 1701.

50 Por. M. Graczyk, Moralna część Katechizmu Kościoła Katolickiego, s. 96.

${ }^{51}$ Por. J. Tarnowski, Wołanie o mistrza. W 30-lecie soborowej Deklaracji o wy- 
A przecież, jak poucza nas historia minionego wieku, od tego, jaką koncepcję człowieka przyjmiemy, zależą praktyczne konsekwencje, wyrażające się często w postaci różnego rodzaju konfliktów ${ }^{52}$. Trzeba więc koniecznie w sposób naukowy, ale także i popularny, szukać odpowiedzi na zasadnicze pytanie: kim jest człowiek ${ }^{53}$ Dlatego, w świetle tego, co zostało powiedziane, nie może pozostać sprawą obojętną, jak dziecko uczy się biologii, nauki o człowieku, historii czy języka ${ }^{54}$. Wszak przekazywanie wartości zależy od przyjętych przesłanek ideału człowieka ${ }^{55}$.

Chodzi więc o to, aby oprzeć pedagogikę na pełnej antropologii i na słusznej etyce oraz określonej aksjologii (teorii wartości), które stanowią fundament dla refleksji o wychowaniu człowieka jako osoby. Doświadczenie człowieka wiąże się z doświadczeniem moralności, udowadnia, że wszelka antropologia abstrahująca od wartości jest okaleczoną wiedzą o człowieku ${ }^{56}$.

Uznanie pełni prawdy o naturze ludzkiej, przyjęcie właściwej antropologii teologicznej jest gwarantem, że człowiek pozna i przeżyje dobro moralne jako wartość doniosłą i przez wierną służbę tym wartościom doświadczy sensu własnego istnienia ${ }^{57}$.

Za powyższą wizją wychowania stoi określona wizja człowieka. Ta wizja, która kazała kiedyś powiedzieć papieżowi, w Warszawie na Placu Zwycięstwa, że „człowieka nie można do końca zrozumieć bez Chrystusa. A raczej: człowiek nie może siebie sam do końca zrozumieć bez Chrystusa. Nie może zrozumieć, ani kim jest, ani jaka jest jego prawdzi-

chowaniu chrześcijańskim z ks. J. Tarnowskim rozmawiają E. Osewska i T. Ochinowski, „Więź” 12 (1995), s. 95.

${ }_{52}$ Por. S. Wielgus, Ideowe zagrożenia współczesnej cywilizacji, w: Katecheza wobec wyzwań wspótczesności, red. R. Czekalski, Płock 2001, s. 20-21.

53 Por. J. Tarnowski, Wołanie o mistrza, s. 95.

${ }_{54}$ Por. M. Jakubiec, Rola rodziny $w$ kształtowaniu sumienia, w: Wychowanie w rodzinie chrześcijańskiej, red. F. Adamski, Kraków 1982, s. 302-303.

55 Por. P. Tomasik, Nauczanie religii w publicznym liceum ogólnokształcącym wobec założeń programowych polskiej szkoły, Warszawa 1998, s. 410.

${ }_{56}$ Zob. J. Zimny, Zasady chrześcijańskiego wychowania, http://www.pedkat. pl/index.php/255-ks-zimny-jan-zasady-chrzescijanskiego-wychowania (data dostępu: 20.09.2016).

57 Por. P. Góralczyk, Wychowawcza etyka seksualna, s. 23. 
wa godność, ani jakie jest jego powołanie i ostateczne przeznaczenie" 58 . Wychowanie, w tym także wychowanie religijne, powinno zawsze sięgać do określonej koncepcji człowieka, gdyż dopiero w oparciu o nią dyskurs pedagogiczny staje się sensowny ${ }^{59}$. Człowiek pozostaje pierwszym podmiotem wychowania, jego adresatem i współtwórcą ${ }^{60}$.

Podstawową intuicję pedagogiczną katolicyzmu stanowi przeświadczenie, że dziecko od samego początku jest osobą, której należy się miłość i której godność powinna być uszanowana ${ }^{61}$. Uzasadnienie godności osoby w antropologii chrześcijańskiej przebiega nie tylko w płaszczyźnie przyrodzonej, co oznacza, że wartość człowieka określana jest takimi elementami, jak: wolność, świadomość i odpowiedzialność, ale przebiega ona przede wszystkim w płaszczyźnie nadprzyrodzonej. W takim ujęciu wartość osoby określana jest jej pochodzeniem od Boga, podobieństwem do Niego, a także faktem wcielenia i odkupienia dokonanym przez Jezusa Chrystusa ${ }^{62}$.

Istotnymi składnikami pełnej wartości osoby są prawda o Bożym podobieństwie człowieka i o wynikającym z faktu odkupienia Bożym usynowieniu człowieka ${ }^{63}$. Jako osoba charakteryzuje się on (człowiek) bowiem posiadaniem siebie, przynależnością do samego siebie, dysponowaniem sobą, nieprzekazywalną odpowiedzialnością za samego siebie, co w praktyce oznacza, że nie może on być zawłaszczony przez żadną instytucję, lecz należy do siebie, nie może być przez żadną inną osobę wykorzystywany, ponieważ sam dla siebie jest celem zasadniczym, nie może być przez nikogo reprezentowany, lecz odpowiada sam za siebie ${ }^{64}$.

${ }^{58}$ Jan Paweł II, Homilia w czasie Mszy św. odprawionej na Placu Zwycięstwa (2 czerwca 1979 r.), Warszawa 1979, nr 3.

${ }_{59}$ Por. K. Misiaszek, Wychowanie chrześcijańskie w świetle Katechizmu Kościoła Katolickiego, s. 89.

${ }^{60}$ Por. tamże, s. 89.

${ }^{61}$ Por. J. Salij, Nauka Kościoła na temat wychowania, „W drodze” 21 (1993) 6, s. 34 .

62 Por. H. Skorowski, Problematyka praw człowieka, Warszawa 1996, s. 20.

${ }_{63}$ Por. J. Kondziela, Chrześcijańskie ujęcie praw człowieka, ChS 63-64 (1978), s. 54-55.

${ }^{64}$ Por. S. Witek, Teologia moralna fundamentalna, cz. I: Antropologia moralna, Lublin 1974, s. 73-75. 
Nie jest oczywiście tak, że tylko chrześcijanie mają wizję człowieka zmierzającą ku ogarnięciu wszystkich wymiarów naszego człowieczeństwa. We współczesnej mentalności zakorzenione są również wizje człowieka jednostronne i okaleczone, których nie da się pogodzić z chrześcijańskim spojrzeniem na człowieka ${ }^{65}$.

Powinniśmy również podwoić czujność wobec oszustwa intelektualistycznego obrazu człowieka. Sugeruje się w nim, że ludzie są istotami dążącymi w sposób zaprogramowany do bezgranicznego poznania, nie ustają nigdy w zdobywaniu informacji, w krytycznym prześwietlaniu i odczarowywaniu świata, deprawowaniu tego, co święte, demaskowaniu dobra i przepędzaniu piękna ze swego życia ${ }^{66}$. Wiąże się to z błędną koncepcją człowieka, która czyni z niego istotę najwyższą i niezależną, podczas gdy jest on istotą stworzoną przez Boga i od Niego zależną, istotą skończoną, która do swoich narodzin, rozwoju i przeżycia nieustannie potrzebuje pomocy innych bliźnich ${ }^{67}$.

Nic więc dziwnego, że społeczeństwo pluralistyczne stoi wobec swoistego kryzysu człowieka, który polega na rosnącym braku zaufania do własnego człowieczeństwa, do samego sensu bycia człowiekiem, do płynącej z tego afirmacji i radości, która jest twórcza ${ }^{68}$.

\section{CHRZEŚCIJAŃSKIE SPOJRZENIE NA KONDYCJĘ MORALNĄ CZŁOWIEKA}

Brak prawdziwego modelu człowieka stwarza warunki do funkcjonowania różnego rodzaju manipulacji. Warunkiem skutecznej manipulacji jest jej niedostrzegalność. Podtrzymywanie więc przez społeczeństwo pluralistyczne tych fałszywych obrazów, które w myśl swoich założeń

${ }_{65}$ Por. J. Salij, Nauka Kościoła na temat wychowania, s. 42.
${ }^{66}$ Por. W. Brzezinka, Wychowanie i pedagogika $w$ dobie przemian kulturowych, Kraków 2005, s. 14.

${ }^{67}$ Por. Jan Paweł II, Przemówienie do świata uniwersyteckiego w Padwie (12 IX 1982), OsRomPol 9 (1982), s. 23.

${ }^{68}$ Por. tenże, Przyszłość człowieka zależy od kultury. Przemówienie wygłoszone 2 czerwca 1980 roku w UNESCO, OsRomPol 6 (1980), s. 5. 
przeczą działaniom manipulatorskim, jeszcze bardziej utrwala i potęguje status samej manipulacji ${ }^{69}$.

O człowieku, jego naturze, godności, sposobie egzystencji wielokrotnie wypowiada się Katechizm Kościoła Katolickiego, dając możliwość nowego spojrzenia na interesujący nas problem. Już we wstępie znajdujemy fundamentalne dla wychowania stwierdzenie o celowości ludzkiego życia: „jest on nie tylko stworzony przez Boga, ale także przez Niego poszukiwany, wspomagany, kochany, a wreszcie przeznaczony do nawiązania z Nim synowskich relacji i życia w szczęśliwości wiecznej”. Dlatego pierwszym zadaniem wychowania religijnego jest pomoc udzielana człowiekowi, aby ten stał się nim rzeczywiście w pełnym wymiarze. Może on uzyskać ten stan rozwoju, jeżeli w wychowaniu znajdzie potwierdzenie własnej tożsamości, mając jasny i trwały obraz siebie samego. Realistyczny obraz samego siebie uzależniony jest od właściwego rozumienia natury człowieka $^{70}$.

Człowiek ze swej natury jest zdolny do dobra. Skoro jednak jego natura została skażona grzechem, człowiek jest również zdolny do zła. Chrześcijańskie spojrzenie na kondycję moralną człowieka jest w pełni realistyczne: jest on istotą ambiwalentną. Pedagogia chrześcijańska uwzględnia właśnie tę dwuznaczność. Wie, że zło może nami owładnąć i że ma wielką siłę przyciągania. Człowiek potrzebuje Odkupienia ${ }^{71}$.

Należy przy tym zgodzić się ze słowami Goethego: „Jeśli będziesz traktował osoby tak, jak na to zasługują, będziesz je czynił gorszymi. Jeżeli będziesz je widział takimi, jakimi mogą się stać, uczynisz je takimi naprawdę"72. Potrzeba bardziej brać pod uwagę to, co jest pozytywne, aniżeli to, co negatywne. Chodziłoby mniej więcej o takie postępowanie wychowawcy, który zamiast mówić dziecku, które uczy się jazdy na rowerze: „uważaj, bo się wywrócisz!” mówi: „teraz patrz spokojnie przed siebie!” Wychowanie religijne jest procesem stale pojmowanych działań, które

69 Por. A. Lepa, Manipulowanie człowiekiem jako problem współczesnej pedagogii, „Ethos” 5 (1992) 1, s. 78-79.

70 Por. K. Misiaszek, Wychowanie chrześcijańskie w świetle „Katechizmu Kościoła katolickiego", s. 89-91.

${ }^{71}$ Por. J. Van der Vloet, Obraz człowieka jako fundament pedagogii, ComP 12 (1992) 3, s. 7.

${ }^{72}$ Cyt. za: G. Pellegrino, Jak wychowywać?, Warszawa 1994, s. 11. 
mają na celu utrwalenie i pogłębienie więzi łączących człowieka z Bogiem i Boga z człowiekiem, sprawianą w nas przez Chrystusa. Wychowanie to charakteryzuje się tym, że jest zespołem czynności niedokonanych. W teologii ascetycznej nazywa się ten stan nieustannym nawracaniem. Nawrócenie religijne jest spowodowanym w nas przez Chrystusa naszym realnym skierowaniem się do Boga. Przebywanie w Jego obecności i poddanie się temu działaniu może mieć postać tylko szczerego skierowania się do prawdy i bezinteresownego czynienia dobra ${ }^{73}$. Celem wychowania chrześcijańskiego tylko wtórnie jest kształtowanie poglądów w duchu nauki Bożej, celem nadrzędnym jest bowiem skłanianie siebie i bliźnich do otwierania się na zbawczą moc Bożą (por. 1 Kor 2,4n.). Ostatecznie istotnym są nie tyle formy i sposoby, jakie przyjmuje sam proces wychowania, ile warunki i postawa wychowawcy, który przez swoje zachowanie i daleko idącą wewnętrzną identyfikację jest niejako częścią przekazywanej prawdy wiary czy wartości. Zaś wychowankowie akceptują go właśnie dlatego, że w nim te prawdy i wartości przyjęły twarz człowieka.

\section{ZASADY CHRZEŚCIJAŃSKIEGO PROCESU WYCHOWANIA}

Najczęściej wymienia się cztery główne zasady chrześcijańskiego procesu wychowania. Ponieważ całokształt działań wychowawczych w Kościele wyprowadzanych jest od Chrystusa i do Chrystusa zmierza, pierwszą z nich jest zasada chrystocentryzmu ${ }^{74}$. Widać ją najbardziej w postulatach wychowania religijnego oraz coraz bardziej doskonałego poznawania i miłowania Boga, zawartych w ideale wychowania ${ }^{75}$.

Chrystocentryzm stanowi źródło, z którego wypływa zasada moralizmu Chrystusowego, opierająca się na prawdzie i miłości, sprawiedliwości i świętości, duchu wolności. Stąd też w procesie wychowania

73 Por. M. Gogacz, Podstawy wychowania, Niepokalanów 1993, s. 45n.

${ }_{74}$ Zob. S. Dziekoński, Podmiotowy charakter wychowawczego działania katechety, w: Dzisiejszy katecheta - stan aktualny i wyzwania, red. J. Stala, Kraków 2002, s. 89-109.

75 Por. S. Kunowski, Teologia a potrzeby pedagogiki katolickiej, AK 51 (1959) 300-302, s. 243; tenże, Podstawy wychowania duszpastersko-katechetycznego, „Katecheta” 6 (1962) 30, s. 210-211; tenże, Podstawowe zasady wychowania w Deklaracji, AK 60 (1968) 359, s. 422. 
akcentuje się przyjmowanie wartości moralnych przez osobisty wybór oraz zgodnie z prawidłowo ukształtowanym sumieniem. Warto tu zaznaczyć, że w świetle nauczania Kościoła wychowanie moralne powinno być przede wszystkim formacją sumienia. Sama „wiedza o tym, co jest dobre, a co złe, nie wystarczy"76. W sumieniu dokonuje się osłabienie wrażliwości na Boga i człowieka wraz ze wszystkimi zgubnymi konsekwencjami tego zjawiska. Doprowadza to do zatarcia granicy pomiędzy dobrem a złem ${ }^{77}$. Dlatego formacja sumienia powinna prowadzić do kształtowania postawy pokuty, pojednania, ukazywać związek między wolnością i prawdą oraz pomagać we właściwym osądzaniu rzeczywistości i dokonywaniu samodzielnych wyborów moralnych ${ }^{78}$. Stąd wypływa konieczność wychowania do odpowiedzialności przez nieustanny wysiłek i przekraczanie siebie oraz do właściwego i odpowiedzialnego korzystania z wolności ${ }^{79}$.

W procesie wychowania ukierunkowanym na wolność i odpowiedzialność należy zaprezentować i przekazać wychowankom kryterium rozpoznawania prawdy i dobra. Sam mechanizm wpajania nawyków zachowania nie wystarczy. Należy jeszcze uzasadnić te zachowania i doprowadzić do uznania ich za dobre przez wychowanków. Jest to ważne, zwłaszcza w obecnej sytuacji, gdy wychowankowie są kształtowani przez mass media, także przez coraz bardziej popularne media techniczne. Zauważalne są także kryzys autorytetów, promowanie mentalności konsumpcyjnej oraz relatywizacja wartości ${ }^{80}$. Wymienione zjawiska są bardzo charakterystyczne dla współczesnych demokracji, które cechuje daleko posunięty relatywizm moralny, narzucający swoją koncepcję tolerancji. Absolutyzowanie relatywizmu moralnego prowadzi do poważnych wypaczeń życia społecznego, gdyż „demokracja bez wartości łatwo się przemienia w jawny lub zakamuflowany totalitaryzm" ${ }^{1}$. Fakt istnienia zsekularyzowanego świata domaga się katechezy pogłębiającej świado-

76 VS 64.

77 Por. EV 24.

78 Por. EV 96.

79 Por. S. Kunowski, Podstawy wychowania duszpastersko-katechetycznego, s. 211; tenże, Podstawowe zasady wychowania w Deklaracji, s. 422.

${ }^{80}$ Por. A. Potocki, Społeczna formacja katechetów, w: K. Misiaszek, A. Potocki, Katecheta i katecheza w polskiej szkole, Warszawa 1995, s. 153.

${ }^{81}$ CA 46. 
mość wiary i prowadzącej do odważnego wyznawania swej tożsamości chrześcijańskiej i katolickiej ${ }^{82}$.

Z powyższych zasad, a szczególnie z moralizmu Chrystusowego, wynikają kolejne. Wśród nich pojawia się zasada personalizmu chrześcijańskiego, który szanuje prawdziwą wolność jako cel, broni praw i godności człowieka, jako osoby ludzkiej. Personalizm pedagogiczny próbuje ukazać we właściwych proporcjach prawa jednostki oraz znaczenie społeczeństwa $\mathrm{w}$ jej indywidualnym rozwoju ${ }^{83}$. Postrzega człowieka jako osobę ludzką stworzoną przez Boga, wolną i powracającą do Niego, zobowiązaną do samourzeczywistnienia się w samowychowaniu poprzez panowanie nad naturą i służbę społeczności. Wychowanek staje się celem wychowania, a nawet celem swego wychowawczego działania ${ }^{84}$. Stąd też $\mathrm{w}$ ujęciu personalizmu pedagogicznego wychowanie polega na umożliwianiu wychowankowi wszechstronnego rozwoju jego własnej osobowości ${ }^{85}$ poprzez angażowanie jego aktywności na tyle, na ile osoba ludzka, świadoma i wolna, może być naprawdę aktywną ${ }^{86}$.

Oprócz zasady personalizmu występuje zasada humanizmu chrześcijańskiego. Wskazuje ona na społeczną naturę człowieka, domagającą się pomocy od innych, a równocześnie wezwaną do jej świadczenia ${ }^{87}$. Wymienione wyżej cztery główne zasady: chrystocentryzmu, moralizmu, personalizmu i humanizmu chrześcijańskiego, działając łącznie, ustawiają wychowanie chrześcijańskie na realizację podwójnego celu: nadprzyrodzonego - dotyczącego zbawienia oraz doczesnego - obejmującego dobro osoby ludzkiej i społeczności ${ }^{88}$.

${ }^{82}$ Por. CT 57.

${ }^{83}$ Por. R. Proietti Segnalini, La pedagogia personalizzata e l'azione pedagogicopastorale nella scuola, Roma 1990, s. 91-92.

84 Por. tamże, s. 230.

${ }^{85}$ Por. Z. Marciniak, Zarys historii wychowania, Warszawa 1978, s. 159; por. także R. Proietti Segnalini, La pedagogia personalizzata e l'azione pedagogico-pastorale nella scuola, s. 97.

${ }^{86}$ Por. P. Viotto, Pedagogia generale, s. 231.

87 Por. S. Kunowski, Podstawy wychowania duszpastersko-katechetycznego, s. 212; tenże, Podstawowe zasady wychowania w Deklaracji, s. 422.

${ }^{88}$ Por. S. Kunowski, Podstawy wychowania, s. 212-213. 
Wytyczenie kierunku, w jakim powinno zmierzać wychowanie chrześcijańskie, jest ściśle związane z celem wychowania, którego określenie i świadomość jest czymś bardzo istotnym, przede wszystkim dla skuteczności działania, jego ekonomiczności i sprawności. ${ }^{89}$ Przyjęty cel wychowania wpływa z kolei, i to w sposób znaczący, na określenie zadań wychowawczych, które prowadzą do osiągnięcia założonych celów ${ }^{90}$.

Humanizująca funkcja pedagogii to przede wszystkim wysiłek na rzecz nieustannego zdobywania potwierdzeń osobowego istnienia, które człowiek powinien doprowadzić do pełnego rozwoju, zamierzonego przez Boga $^{91}$. W pełni humanizująca funkcja wychowania może stać się taką, gdy podkreśli się przede wszystkim godność osoby ludzkiej, której fundament znajduje się nie tylko w samym fakcie człowieczeństwa, ale także w ścisłym związku człowieka z Chrystusem ${ }^{92}$.

Wychowanie - zaznaczył Jan Paweł II w obszernym przemówieniu z 15 V 1982 r. na temat rodziny - służy w szczególnym tego słowa znaczeniu uczłowieczeniu człowieka. Człowiek, będąc człowiekiem od pierwszej chwili swego poczęcia w łonie matki, stopniowo uczy się być człowiekiem. Człowiek jest przyszłością swej rodziny i całej ludzkości - jednakże przyszłość człowieka związana jest nierozerwalnie z wychowaniem ${ }^{93}$.

\section{BIBLIOGRAFIA}

Benedykt XVI, Deus caritas est. Encyklika o miłości chrześcijańskiej, Watykan 2005. Bergoglio, J. M., papież Franciszek, Wymagania i pasja. O wychowaniu chrześcijańskim, Kraków 2013.

Brzezinka, W., Wychowanie i pedagogika w dobie przemian kulturowych, Kraków 2005.

Cichoń, W., Aksjologiczne ujęcie procesu wychowania, w: Człowiek - wartości - wychowanie, red. F. Adamski, Kraków 1993, s. 121-140.

89 Por. S. Dziekoński, Wychowanie w nauczaniu Kościoła, s. 54, 75.

90 Por. PWS, s. 35.

${ }^{91}$ J. Van der Vloet, Obraz człowieka jako fundament pedagogii, s. 24.

${ }_{92} \mathrm{~K}$. Misiaszek, Wychowanie chrześcijańskie w świetle Katechizmu Kościoła Katolickiego, s. 91. Zob. KKK, cz. III: Życie w Chrystusie, nr 2288-2301.

${ }^{93}$ Jan Paweł II, Homilia podczas Mszy dla rodzin, Braga-Monte Sameiro, $15 \mathrm{~V}$ 1982, w: Jan Paweł II, Nauczanie papieskie, t. V/1, Poznań 1982, s. 741. 
Cogiel, M., Kontrowersje wokół wychowania. Dylematy teorii i praktyki edukacyjnej, „Śląskie Studia Historyczno-Teologiczne” 27-28 (1995), s. 53-63.

Cogiel, M., Wychowanie personalistyczne wobec nowego paradygmatu edukacji, AK 136 (2001) 552, s. 283-290.

Dziekoński, S., Podmiotowy charakter wychowawczego działania katechety, w: Dzisiejszy katecheta - stan aktualny i wyzwania, red. J. Stala, Kraków 2002, s. 89-109.

Dziekoński, S., Wychowanie w nauczaniu Kościoła od XIX w. do Soboru Watykańskiego II, Warszawa 2000.

Exeler, A., L'educatione religiosa. Unitinerario alla maturazione dell'uomo, Torino 1990.

Gałkowski, S., Celowość a wychowanie, w: Wybrane zagadnienia z psychologii wychowawczej, red. A. Gała, Wrocław 1994, s. 7-18.

Gogacz, M., Podstawy wychowania, Niepokalanów 1993.

Góralczyk, P., Trudny proces wychowania, „Sosnowieckie Studia Teologiczne” 7 (2005), s. $155-169$.

Góralczyk, P., Wychowawcza etyka seksualna, Ząbki 2000.

Jan Paweł II, Homilia podczas Mszy dla rodzin, Braga-Monte Sameiro, 15 V 1982, w: Jan Paweł II, Nauczanie papieskie, t. V/1, Poznań 1982, s. 741.

Jan Paweł II, Homilia w czasie Mszy św. odprawionej na Placu Zwycięstwa (2 czerwca 1979 r.), Warszawa 1979, nr 3.

Jan Paweł II, Przemówienie do przedstawicieli świata nauki (Lublin, 9 VI 1987), w: Jan Paweł II, Pielgrzymki do Ojczyzny, red. J. Poniewierski, Kraków 1997, s. 398.

Jan Paweł II, Przemówienie na uniwersytecie w Padwie (12.09.1982), w: Jan Paweł II, Wiara i kultura, Rzym-Lublin 1998, s. 161-163.

Kadziński, T., Powinność wychowawcza Kościoła - szkoła katolicka, „Paedagogia Christiana" 4 (1999), s. 104-112.

Katechizm Kościoła Katolickiego, Poznań 1994.

Kondziela, J., Chrześcijańskie ujęcie praw człowieka, ChS 63-64 (1978), s. 54-55.

Kongregacja Nauki Wiary, Libertatis nuntius. Instrukcja, w: Dokumenty Kongregacji Nauki Wiary 1966-1994, opr. Z. Zimowski, J. Królikowski, Tarnów 1995, s. 215-235.

Krąpiec, M. A., Człowiek podmiotem wychowania, „Zeszyty Formacji Katechetów” 4 (2004) 2, s. 25-29.

Kukołowicz, T., Wychowanie - arcyludzki problem, w: Wychowawca na czas próby. Jakiego człowieka chcemy wychować?, Marki-Struga 1997, s. 11-32.

Kunowski, S., Podstawowe zasady wychowania w Deklaracji, AK 60 (1968) 359, s. 414-424.

Kunowski ,S., Podstawy współczesnej pedagogiki, Warszawa 1993.

Lepa, A., Manipulowanie człowiekiem jako problem współczesnej pedagogii, „Ethos” 5 (1992) 1, s. 77-87.

Maritain, J., Od filozofii człowieka do filozofii wychowania, w: Człowiek, wychowanie, kultura, red. F. Adamski, Kraków 1993, s. 61-79.

Matulka, Z., Samowychowanie chrześcijańskie, Toruń 1995.

Misiaszek, K., Wychowanie chrześcijańskie w świetle Katechizmu Kościoła Katolickiego, ChS 23 (1993) 4, s. 88-101. 
Nagórny, J., Chrześcijańskie wychowanie do wartości moralnych, „Seminare” 10 (1994), s. 69-92.

Niparko, R., Wychowanie religijne jako wychowanie humanistyczne - perspektywa personalistyczna, „Paedagogia Christiana” 2 (2003), s. 9-22.

Nowak, M., Podstawy pedagogiki otwartej, Lublin 1999.

Nowak, M., Wychowanie religijne w pedagogice katolickiej XX wieku, „Paedagogia Christiana" 1 (2001), s. 43-69.

Nowak, M., Wychowanie w personalizmie, ChS 4 (1993), s. 60-64.

Orczyk, A., Założenia filozoficzne i wychowawcze chrześcijańskiej pedagogiki personalistycznej, „Zeszyty Formacji Katechetów” 2 (2004), s. 39-43.

Pasternak, W., Dydaktyka wartości, w: Człowiek - wychowanie - kultura, red F. Adamski, Kraków 1993, s. 146-158.

Pellegrino, G., Jak wychowywać?, Warszawa 1994.

Proietti Segnalini, R., La pedagogia personalizzata e l'azione pedagogico-pastorale nella scuola, Roma 1990.

Sobór Watykański II, Gravissimum educationis. Deklaracja o wychowaniu chrześcijańskim, w: Sobór Watykański II, Konstytucje, Dekrety, Deklaracje, Poznań 2002.

Tarnowski, J., Jak wychowywać?, Warszawa 1993

Tarnowski, J., Wołanie o mistrza. W 30-lecie soborowej Deklaracji o wychowaniu chrześcijańskim z ks. J. Tarnowskim rozmawiają E. Osewska i T. Ochinowski, „Więż” 12 (1995), s. 81-95.

Tomasik, P., Nauczanie religii w publicznym liceum ogólnokształcacym wobec założeń programowych polskiej szkoły, Warszawa 1998.

Vloet, J. van der, Obraz człowieka jako fundament pedagogii, ComP 12 (1992) 3, s. 3-11.

Wychowanie chrześcijańskie a kultura, red. M. Nowak, T. Ożóg, Lublin 2000.

Zimny, J., Zasady chrześcijańskiego wychowania, http://www.pedkat.pl/index.php/255ks-zimny-jan-zasady-chrzescijanskiego-wychowania (data dostępu: 20.09.2016). 